\section{Watching television and being affected by television according to the opinions of parents of children between the ages of three and six}

Üç - altı yaş arası çocukların ebeveynlerinin görüşlerine göre televizyon izleme ve televizyondan etkilenme durumlari ${ }^{1}$

\section{Kübra Demir ${ }^{2}$ \\ Nuriye Yıldırım Şişman ${ }^{3}$}

\begin{abstract}
Aim: The aim of this study is to examine the opinions of parents who have three to six years old children on the status of their children watching television and the effects of television on their children.
\end{abstract}

Method: This is a sectional study. 256 parents participated in the study. The participation rate was $80 \%$.A questionnaire form created by reviewing the literature was used as a data collection.

Findings: Of the participating parents, $71.9 \%$ were female. Of the families, $23.0 \%$ had two televisions, and $6.2 \%$ of the participating children had a television in their room; $45.7 \%$ started to watch television after the age of two. The television was watched most in the evening hours $(55.1 \%)$ and $63.7 \%$ of the children watched for one or two hours, while 33.6\% watched for three hours or more in a day. The television was kept on for five-eight hours in $49.2 \%$ of the houses. Changes due to watching television were witnessed in the behaviors of
Özet

Amaç: Bu çalışmanın amacı, üç - altı yaş çocuğu olan ebeveynlerin, çocuklarının televizyon izleme durumlar1 ve televizyonun çocukları üzerine etkilerine yönelik görüşlerinin incelenmesidir.

Yöntem: Kesitsel bir araştırmadır. Çalışmaya 256 ebeveyn katılmıs olup katılım oranı $\% 80$ bulunmuştur. Veriler literatürden yararlanılarak oluşturulan soru formu kullanılarak toplanmıştır.

Bulgular: Çalışmaya katılan ebeveynlerin \%71.9'unu anneler oluşturmaktadır. Evlerin $\% 23.0$ ' de 2 televizyon vardır ve çocukların $\%$ 6.2'nin odasinda televizyon bulunmaktadır. Çocuklar akşam saatlerinde (\%55.1) daha çok televizyon izlemektedir. Çocukların \%63.7'si televizyon programlarını günde 1-2 saat, \%33.6's1 ise 3 saat ve üzeri izlemektedir. Evlerin \%49.2"sin de televizyon 5 - 8 saat açık kalmaktadır. Çocukların \% 77.5'inde olumsuz davranış değişimi olmaktadır.Çocukların \%45.7'si 2 yaşından itibaren televizyon

\footnotetext{
${ }^{1} 20$ - 22 Aralık 2018'de Düzce'de düzenlenen 'Uluslararası Kamu Politikaları Sempozyumu: Bir Kamu Politikası olarak Bağımlılıkla Mücadelede Yeni Yaklaşımlar ve Başarılı Örnekler’ sempozyumun da sözel bildiri olarak sunulmuştur.

2 Master's Nurse, Marmara University Pendik Training and Research Hospital, Pediatrics Intensive Care Unit, demrkubra45@gmail.com (iD) Orcid ID: 0000-0003-1732-6237

3 Assoc. Prof., Duzce University, Faculty of Health Sciencesi Nursing Department, nuriye3@gmail.com nuriyeyildirim@duzce.edu.tr. , (D) Orcid ID: 0000-0003-3745-3751
} 
Demir, K., \& Yıldırım Şişman, N. (2021). Üç - altı yaş arası çocukların ebeveynlerinin görüşlerine göre televizyon izleme ve televizyondan etkilenme durumlar1. Journal of Human Sciences, 18(3), 349-363. doi:10.14687/ihs.v18i3.6048

$43,4 \%$ of the children, and $77.5 \%$ of these changes were found to be negative. The children watched cartoons (36.4\%), kids' programs $(23.7 \%)$, documentaries $(11.5 \%)$, and advertisements $(10.7 \%)$ the most. Children were found to be most affected by the behaviors of cartoon characters $(39.5 \%)$.

Conclusions: This study indicates that the majority of the children between the ages of three and six years watch television for too long; the child participants watched cartoons and kids' programs, and were influenced by cartoon characters' behaviors the most; a majority of the parents believed that their children would prefer games over television; a majority of the children occasionally slept late after they had watched television; watching television for too long reduced their social activity, and caused them to have nightmares and to be aggressive. The amusing and educational television programs and letting children watch television to kill time are significant for children's health

Keywords: Children, nurses, preschool, television, parents.

(Extended English summary is at the end of this document) izlemeye başlamıștır. Çocuklar en çok çizgi film (\%36.4), çocuk programları (\%23.7), belgesel $(\% 11.5)$ ve reklamlar1 (\%10.7) izlemektedir. Çocuklar en çok çizgi film kahramanlarının davranış şeklinden etkilenmektedir.

Sonuç: Çalışmada 3-6 yaş grubu çocukların çoğunluğunun evde televizyon izleme ve televizyonun evde açık kalma sürelerinin uzun olması, çocukların en çok çizgi film ve çocuk programlar1 izlemeleri, çizgi film kahramanlarının en çok davranışlarından etkilenmeleri, uzun süre televizyon izlemenin çocukların sosyalliklerinin azalmasına, kabus görmelerine ve saldırganlığına sebep olduğu ve televizyonun eğlendirici, eğitici-öğretici olmas1 nedeni ile televizyon izletilmesi önemli sonuçlardır.

Anahtar Kelimeler: Çocuklar; hemşireler; okul öncesi; televizyon; ebeveynler.

\section{Giriş}

Okul öncesi dönem, sosyal becerilerin geliştiği bir dönemdir. Bilişsel ve sosyal gelişimi sağlıklı şekilde desteklenen çocukların ileri yaşlarda uyum ve başarı düzeyleri daha olumlu olabilmektedir (Koçak, Pınarcık ve Ergin, 2015). Televizyon (TV), çocuğu etkileyen, kolaylıkla ulaşılabilen en önemli kitle iletişim aracıdır (Güngör, 2014). Aynı zamanda da bağımlılık yapabilen en popüler eğlencedir (Sussman ve Moran, 2013). Televizyonun göze ve kulağa hitap eden etkili bir iletişim aracı olmasından dolayı, gelişim döneminde olan çocukların televizyona ilgisi daha yoğun olmakta ve boş zamanlarını TV karşısında geçirmektedirler. Bu da ailelerinden çok TV ile vakit geçirmelerini sağlamaktadır (Kırık, 2013). TV, ebeveynler tarafından çocukları meşgul edecek iyi bir çocuk bakıcısı' olarak da değerlendirilebilmektedir (De Decker ve ark., 2012). TV izlemenin çocukların bilgisini arttırıp, hayal gücünü genişletme gibi etkileri vardır. Ancak uzun süre TV izleyen çocuklarda sosyalleşme ve iletişsim sorunları da görülebilmektedir (Babaroğlu, 2015). Çocuk sağlı̆̆1 ve gelişimine katkıda bulunan iki davranış fiziksel aktivite ve TV izlemedir (Hinkley ve McCann, 2018). Uzun süreli TV izlemek çocuğun fiziksel aktivitesini de azaltmaktadır. Çocuklar TV programlarını TV dışında tabletler ve akıllı telefonlar gibi farklı dijital araçlardan ebeveynlerinin kontrolü olmaksızın izleyebilmektedirler. Tabletler ve akıllı telefonların kullanımı günümüzde televizyon kadar kolay olduğu için, bu cihazlar, televizyonu destekleyici bir ortam halini almaktadırlar (Çelik A, 2019). Bilgisayar, telefon ve tabletin de TV programları izleme de etkisi olabildiğinden evdeki televizyon sayısı yanında, diğer dijital cihazlarında çocuk tarafindan ne derece kullanıldığının bilinmesinin gerekliliği de ortaya çıkmıştır. 
Demir, K., \& Yıldırım Şişman, N. (2021). Üç - altı yaş arası çocukların ebeveynlerinin görüşlerine göre televizyon izleme ve televizyondan etkilenme durumlar1. Journal of Human Sciences, 18(3), 349-363. doi:10.14687/jhs.v18i3.6048

Yapılan bir meta-analiz çalışmasında, TV izleme süresi artmasının, çocukluk obezite riskinin artmasıyla ilişskili olduğu ortaya konulmuştur (Zhang ve ark., 2015). TV izlemek, daha fazla yiyecek ve tatli içecek tüketimi ile de ilişkili bulunmuştur (De Craemer ve ark., 2012). Okul öncesi çocuklarda gıda reklamcilı̆̆ da dahil olmak üzere televizyon reklamları şişmanlık ile ilişkili bulunmuştur (Zimmerman ve Bell, 2010). Akçay ve Özcebe'nin (2012) okul öncesi çocuklarla yaptığ1 çalışmada; çocukların TV izleme süresi arttıkça olumlu sosyal davranışların azaldığ1, saldırganlıklarının arttı̆ı saptanmıştır. Dokuz devlet anaokulunda yapılan çalışmada çocukların oyunlarını popüler televizyonun hikâyeleri ve karakterlerinden ürettiği belirlenmiştir (Akçay, 2018). Bu bağlamda çocuğun toplumsal kimlik gelişimi ve sosyalleşmesinde TV etkin bir rol oynamaktadır (Babaroğlu, 2015).

Çocuklar çoğunlukla dizi, film, reklâm ve çizgi filmleri izlemektedir. Gerçek ile gerçek olmayanı ayıramayan çocuğun ebeveynleri tarafindan yönlendirilmesi gerekmektedir (Kırı, 2013). Çocuğun gelişimsel ihtiyaçlarını karşılayan, şiddet yerine pozitif sosyal değerleri içeren programlar izletilmeye çalışılmalıdır (Güngör, 2014). Hemşireler, ebeveynlere, çocuk bakıcılarına ve okul öncesi öğretmenlerine TV'nin okul öncesinde kullanımı, medya okuryazarlığ1 hakkında danışmanlık sağlamalıdır. Sağlıklı nesillerin oluşturulması için, çocukların TV izleme alışkanlıklarının değerlendirilmesi, ekran başında kalma süresini sınırlanması, izlenen içeriğin kontrolünün sağlanması, evde farklı aktivitelerle çocuğun TV izleme süresinin sınırlanması, çocuklarla kaliteli vakit geçirilmesi konuları çocuklara ve ebeveynlere sağlanan hemşirelik bakımı içinde yer almalıdır. Literatürde bu konuda yapılacak çalışmalara ihtiyaç vardır. Bu bağlamda çalışmanın amacı, ebeveynlerin televizyonun 3-6 yaş çocukları üzerindeki etkilerine yönelik görüşlerinin incelenmesidir.

\section{Materyal ve Metod}

\subsection{Araştırmanın türü ve yapıldığ yer}

Araştırmanın türü tanımlayıcı ve kesitseldir. Araştırma, XXX ili, Merkez bölgesinde, Milli Eğitim Bakanlığına bağlı 11 anaokulunda, Mart - Mayıs 2017 tarihleri arasında yapılmıştır.

\subsection{Araştırma evreni ve örneklemi}

Araştırma evrenini XXX ili, Merkez bölgesinde bulunan 11 Anaokuluna kayıtlı 3-6 yaş grubu çocukları olan 1016 ebeveyn oluşturmaktadır. Örneklem sayısı; 1016 ebeveynden \%30.0'luk tabakalama örnekleme yöntemi kullanılarak 306 ebeveyn olarak alınmıştır (Blanche ve ark. 2006). Çalışmaya 256 ebeveyn katılmış olup katılım oranı \%80 bulunmuştur.

Tablo: 1. Örnekleme Alınan Okullar

\begin{tabular}{|c|c|c|c|}
\hline $\begin{array}{l}\text { XXX İl Merkezinde Bulunan } \\
\text { Devlet Anaokulları Listesi }\end{array}$ & $\begin{array}{llr}\text { Okullarda } & 3-6 & \text { yaş } \\
\text { aralığında } & \text { bulunan } \\
\text { ebeveyn sayısı } & & \\
\end{array}$ & $\begin{array}{ll}\text { Tabakalı } & \text { yöntemle } \\
\text { alınan } & \text { örneklem } \\
\text { sayısı } & \\
\end{array}$ & $\begin{array}{l}\text { Ulaşılan örneklem } \\
\text { sayısı }\end{array}$ \\
\hline Anaokulu 1 & 130 & 39 & 30 \\
\hline Anaokulu 2 & 120 & 36 & 32 \\
\hline Anaokulu 3 & 150 & 45 & 41 \\
\hline Anaokulu 4 & 40 & 12 & 10 \\
\hline Anaokulu 5 & 105 & 32 & 22 \\
\hline Anaokulu 6 & 86 & 26 & 21 \\
\hline Anaokulu 7 & 40 & 12 & 10 \\
\hline Anaokulu 8 & 45 & 14 & 11 \\
\hline Anaokulu 9 & 50 & 15 & 10 \\
\hline Anaokulu 10 & 110 & 33 & 30 \\
\hline \multirow[t]{2}{*}{ Anaokulu 11} & 140 & 42 & 39 \\
\hline & $\begin{array}{l}\text { Toplam } \\
\text { Büyüklüğü: } 1.016\end{array}$ & Örneklem sayıs1:306 & $\begin{array}{l}\text { Ulaşılan örneklem } \\
\text { sayıs1:256 }\end{array}$ \\
\hline
\end{tabular}


Demir, K., \& Yıldırım Şişman, N. (2021). Üç - altı yaş arası çocukların ebeveynlerinin görüşlerine göre televizyon izleme ve televizyondan etkilenme durumlar1. Journal of Human Sciences, 18(3), 349-363. doi: $10.14687 /$ ihs.v18i3.6048

\subsection{Veri toplama arac1}

Veriler literatürden yararlanılarak hazırlanan soru formu ile toplanmışır (Kırık, 2013; De Decker ve ark., 2012; Hinkley ve McCann, 2018; Zhang ve ark., 2015; De Craemer ve ark., 2012; Dorey ve ark., 2010; Yetim ve Sarıçam, 2016; Ferrari ve ark., 2015). Soru formu; demografik özelliklere ait 7 soru, çocuklarnn televizyon izleme durumlanna ait 16 soru, ebeveynlerin televizyonun etkilerine ilişkin tutum ve davranışlarına yönelik bilgileri elde etmeye ilişkin 17 soru olmak üzere 40 sorudan oluşmuştur.

\subsection{Veri toplama}

Verilerin toplanması aşamasında anaokulundaki müdür ve öğretmenlere açıklama yapılmıştır. Ebeveynlere soru formu çocuklar aracılı̆̆ıyla kapalı zarf içerisinde eve gönderilmiştir. Ebeveynlere 350 adet kapalı zarf içerisinde gönderilen anket formlarından 256 ebeveynden dönüş olmuştur. Çalışmayı kabul etmeyen ebeveynlerin katılmama sebeplerine dair bir geri bildirim alınmamıștır.

\subsection{Araştırmanın etik yönü}

Araştırma için XXX Üniversitesi Sağlık Bilimleri Enstitüsü Etik Kurul Başkanlığı'ndan 2017/02/29 tarihinde onay ve XXX Milli Eğitim Müdürlüğü'nden yasal izin alınmıştır. Araştırmaya katılan ebeveynlere çalışma hakkında yazılı bilgi verilerek, çalışmaya katılma konusunda özgür oldukları, verilerin gizli tutulacağı, bilimsel çalışma dışında kullanılmayacağı belirtilerek yazılı onamları alınmıştır.

\subsection{Verilerin değerlendirilmesi}

Verilerin kodlanması ve değerlendirilmesinde IBM SPSS Statistics 23 program1 kullanılmıştır. Çalışmadan elde edilen verilerin tanımlayıcı istatistiklerinde sayı, yüzde, ortalama ve standart sapma kullanılmıştır.

\subsection{Araştırmanın sinırlılıkları}

Araştırmanın bulguları sadece bu çalışmaya katılan ebeveynlerin öznel değerlendirmeleri ile sınırlı olduğundan, sonuçlar bu ebeveynlere genellenebilir. Çalışma kesitsel nitelikte olduğu için araştırma sonuçlarından kesin bir neden sonuç ilişkisine ulaşılamaz.

\section{Bulgular}

Çalışmadan elde edilen verilere bakıldığında; ebeveynlerin \%71,9’unu anneler oluşturmakta, \%39.1'i lise mezunu, \%91.0'i çekirdek aile, \%73.8'nin geliri giderine denk, \%56.2'nin çalışmakta olduğu ve \%61.3'nün toplamda iki çocuk sahibi oldukları saptanmıştır, Ebeveynlerin yaş ortalaması $32.94 \pm 4,10$ bulunmuştur (Tablo 2).

Tablo 2. Ebeveynlerin sosyo-demografik özelliklere göre dağılımı $(\mathrm{n}=256)$

\begin{tabular}{lrr}
\hline & $\mathbf{n}$ & $\mathbf{\%}$ \\
\hline Aile içindeki rolleri & & \\
$\quad$ Anne & 184 & 71.9 \\
Baba & 72 & 28.1 \\
Eüitim düzeyi & 61 & 23.8 \\
$\quad$ Illkokul - ortaokul & 100 & 39.1 \\
$\quad$ Lise & 95 & 37.1 \\
$\quad$ Üniversite ve üstü & & \\
Aile Tipi & 233 & 91.0 \\
$\quad$ Çekirdek aile & 23 & 9.0 \\
$\quad$ Geniş aile & & \\
Ekonomik durum & 36 & 14.1 \\
$\quad$ Gelir giderden az & 189 & 73.8 \\
$\quad$ Gelir gidere denk & 31 & 12.1 \\
Gelir giderden fazla & &
\end{tabular}


Demir, K., \& Yıldırım Şişman, N. (2021). Üç - altı yaş arası çocukların ebeveynlerinin görüşlerine göre televizyon izleme ve televizyondan etkilenme durumları. Journal of Human Sciences, 18(3), 349-363. doi:10.14687/ihs.v18i3.6048

\section{Çalışma durumu}

Çalış̧an

Çalışmayan

144

112

56.2

Çocuk Sayısı

$\begin{array}{lrr}1 \text { çocuk } & 52 & 20.3 \\ 2 \text { çocuk } & 157 & 61.3 \\ 3 \text { çocuk ve üstü } & 47 & 18.4\end{array}$

\begin{tabular}{lll}
\hline Katılımcıların Yaş1 & (Ort \pm SD) (Min- Max) & $32.94 \pm 4.10(22-49)$
\end{tabular}

Tablo 3.'ye bakıldığında, ailelerin \%23.0'nde iki televizyon bulunduğu, \% 6.2' nde çocuğun odasında TV bulunduğu, çocukların \%55.1'inin en çok akşam vakti TV izlediği, çocukların $\%$ 63.7'sinin TV programlarını günde 1-2 saat, \%33.6'nın 3 saat ve üstü izlediği, evlerin \%49.2'sin de TV'nin açık kalma süresinin 5-8 saat olduğu belirlenmiştir. Ebeveynlerin \%62.5’i televizyonu açtıklarında çocuklarının çevreye ilgisinin ara sıra azaldığını, ebeveynlerin \%43.4'nün televizyonun çocuklarında davranış değişikliğine sebep olduğunu, bunların \%77.5'inin çocuktaki davranış değişiminin olumsuz olduğunu ve ebeveynlerin \%45.7'si iki yaşından itibaren çocuklarının televizyon izlediğini ifade etmişlerdir (Tablo 3).

Tablo 3. Çocukların televizyon izleme durumlarına ait bilgiler $(n=256)$

\begin{tabular}{|c|c|c|}
\hline & $n$ & $\%$ \\
\hline \multicolumn{3}{|c|}{ Evde bulunan televizyon sayısı } \\
\hline TV yoktur & 1 & 0.4 \\
\hline 1 adet & 189 & 73.8 \\
\hline 2 adet & 59 & 23.0 \\
\hline 3 adet & 7 & 2.7 \\
\hline \multicolumn{3}{|c|}{ Çocuğun odasında televizyon bulunması } \\
\hline Bulunan & 16 & 6.2 \\
\hline Bulunmayan & 240 & 93.8 \\
\hline \multicolumn{3}{|c|}{ Çocuğun en çok televizyon izlediği vakit } \\
\hline Sabah & 62 & 24.2 \\
\hline Öğle & 53 & 20.7 \\
\hline Akşam & 141 & 55.1 \\
\hline \multicolumn{3}{|c|}{ TV günde ortalama izleme süresi } \\
\hline Hiç izlemiyor & 7 & 2.7 \\
\hline $1-2$ saat & 163 & 63.7 \\
\hline 3 saat ve üstü & 86 & 33.6 \\
\hline \multicolumn{3}{|c|}{ Televizyonun bir günde açık kalma süresi } \\
\hline İzlenmiyor & 16 & 6.2 \\
\hline $1-4$ saat & 58 & 22.7 \\
\hline 5-8 saat & 126 & 49.2 \\
\hline 9 saat ve üstü & 56 & 21.9 \\
\hline \multicolumn{3}{|c|}{ Televizyon açıldığında çocuğun çevreye olan ilgisi } \\
\hline Azaliyor & 34 & 13.3 \\
\hline Azalmiyor & 62 & 24.2 \\
\hline Ara sira azaliyor & 160 & 62.5 \\
\hline \multicolumn{3}{|c|}{ Televizyon izlemeye bağlı davranış değişimi } \\
\hline Oluyor & 111 & 43.4 \\
\hline Olmuyor & 145 & 56.6 \\
\hline \multicolumn{3}{|c|}{ Televizyon izlemeye bağlı davranış değişiminin içeriği $(n=111)$} \\
\hline Olumlu & 25 & 22.5 \\
\hline Olumsuz & 86 & 77.5 \\
\hline
\end{tabular}


Demir, K., \& Yıldırım Şişman, N. (2021). Üç - altı yaş arası çocukların ebeveynlerinin görüşlerine göre televizyon izleme ve televizyondan etkilenme durumlar1. Journal of Human Sciences, 18(3), 349-363. doi:10.14687/ihs.v18i3.6048

Televizyon izlemeye başlanan yaş

1 yaş

12.9

2 yaş

117

45.7

3 yaş

82

32.0

4 yaş

20

7.8

5 yaş

4

1.6

Çocuğun izlediği TV programları(n=663) *

Belgesel

Çizgi film

Müzik programları

Dizi

Film

Reklamlar

Çocuk programları

Haberler

Çizgi film kahramanlarından etkilendiği özellikler

Konuşma şekli

Davranış şekli

Jest ve mimikler

Etkilenmiyor

Çocuğun öncelikli etkinlik tercihi

Televizyon izleme

Resim çizme

Boyama

Oyun oynama

Çocuğun televizyon reklamlarını izleme durumu

Çoğunlukla

Ara sira

İzlemiyor

Çocuğun İzlediği reklam türü $(n=208)$

Yiyecek

İçecek

Oyuncak

TV izleme nedeniyle geç yatma

Çoğunlukla oluyor

Ara sira oluyor

Olmuyor

TV izleme nedeniyle yaşanan sorunlar $(n=360)$ *

Uyuyamama

Kâbus görme

Saldırganlik

Baş. Boyun. Sırt ağrısı çekme

Kaygili davranma

Sosyalliğin azalması

Tepki vermeme

Yemek yememe 
Demir, K., \& Yıldırım Şişman, N. (2021). Üç - altı yaş arası çocukların ebeveynlerinin görüşlerine göre televizyon izleme ve televizyondan etkilenme durumları. Journal of Human Sciences, 18(3), 349-363. doi:10.14687/ihs.v18i3.6048

Ebeveynler, çocuklarının en çok çizgi film (\%36.7), çocuk programları (\%23.7), belgesel $(\% 11.5)$ ve reklamları (\%10.7) izlediklerini, çocukların \%39.5'inin televizyondaki çizgi film kahramanlarının davranış şeklinden etkilendiklerini, ebeveynlerin \%64.8’i çocuklarına seçenek sunulduğunda oyun oynayacaklarını, çocukların \%71.1'inin reklamları ara sıra izlemekten hoşlandığını ve bu reklamların \%73.0'ünün oyuncak reklamları olduğunu ifade etmişlerdir. Ebeveynlerin, \%50.0'si çocuklarının televizyon izlerken ara sıra geç yattığını, uzun süre televizyon izlemenin çocuklarının sosyalliklerinin azalmasına (\%26.8), kabus görmeye (\%17.0) ve saldırganlığa (\%15.8) sebep olduğu saptanmıştır (Tablo 3).

Tablo 4. Ebeveynlerin televizyonun çocukları üzerine etkilerine yönelik görüşleri $(n=256)$

\begin{tabular}{lrr}
\hline & $\mathbf{n}$ & $\mathbf{\%}$ \\
\hline TV izlemenin çocuğun insanlarla ilişkisi üzerine etkisi & & \\
Olumlu etkiliyor & 20 & 7.8 \\
Bazen olumlu bazen olumsuz etkiliyor & 219 & 85.5 \\
Olumsuz etkiliyor & 17 & 6.6 \\
TV izlemenin çocuğun hayal dünyası üzerine etkisi & & \\
Olumlu etkiliyor & 21 & 8.2 \\
Bazen olumlu bazen olumsuz etkiliyor & 215 & 84.0 \\
Olumsuz etkiliyor & 20 & 7.8
\end{tabular}

Uzun süre TV izlemenin çocuğun arkadaşları ile sosyalleşmesi ve oyun oynaması üzerine etkisi

$\begin{array}{lcc}\text { Etkiliyor } & 126 & 49.2 \\ \text { Etkilemiyor } & 74 & 28.9 \\ \text { Bazen etkiliyor } & 56 & 21.9\end{array}$

Uzun süre ve kontrolsüz televizyon izlemenin çocukları duyarsızlaştırdığına ve tepkisiz hale getirdiğine inanma durumu

$\begin{array}{lcr}\text { İnaniyorum } & 187 & 73.0 \\ \text { İnanmiyorum } & 20 & 7.8 \\ \text { Bazen inaniyorum } & 49 & 19.1\end{array}$

Televizyon yayınlarının aile içindeki iletişime etkisi

Olumlu etkiliyor $\quad 6 \quad 62.3$

Bazen olumlu bazen olumsuz etkiliyor $\quad 182 \quad 71.1$

$\begin{array}{lrr}\text { Olumsuz etkiliyor } & 68 & 26.6\end{array}$

Çocuğunuz televizyon programlarını izlediği kişiler $(n=254)$

$\begin{array}{lll}\text { Kendisi yalnız izler } & 60 & 23.4\end{array}$

$\begin{array}{lrr}\text { Arkadaşlarıyla beraber izler } & 8 & 3.1\end{array}$

$\begin{array}{lll}\text { Aileyle birlikte izler } & 186 & 83.5\end{array}$

Çocuğun istediği anda televizyonu açabilmesi
Açar

Açamaz $\quad 55 \quad 21.5$

Ara sira açar $\quad 101 \quad 39.5$ 
Demir, K., \& Yıldırım Şişman, N. (2021). Üç - altı yaş arası çocukların ebeveynlerinin görüşlerine göre televizyon izleme ve televizyondan etkilenme durumlar1. Journal of Human Sciences, 18(3), 349-363. doi:10.14687/jhs.v18i3.6048

Tablo 4'e göre, ebeveynlerin çocuklarının televizyon izlemesinin insanlarla ilişki kurmasında (\%85.5) ve hayal dünyası üzerine (\%84.0) bazen olumlu bazen olumsuz şekilde etkilendiğini, uzun süre televizyon yayını izlemenin çocuğun sosyallik ve oyun oynamasını (\%49.2) etkilediğini, \%73.0’ü çocuğu duyarsızlaştırdığını ve tepkisiz hale getirdiklerine inanmaktadır. Televizyon izlemenin aile içi iletişimi bazen olumlu bazen olumsuz etkilediği (\%71.1), çocukların çoğunluğunun televizyonu aileyle birlikte izlediği (\%73.5) ve çocukların canı istediğinde (\%39.1) ya da ara sıra (\%39.5) kendisinin TV açtığ1 saptanmıştır.

\section{Tartı̧̧ma}

Çocuk sağlığının korunması ve geliştirilmesi için koruyucu sağlık hizmetleri dahilinde evde ya da okulda çocuğun TV izlemesinin değerlendirilmesi hemşirelerin yapacakları girişimler için önemlidir. Elde edilen veriler, bu konuda yapılacak müdahale çalışmalarına zemin oluşturabilecektir. Bu çalışma, üç - altı yaş çocuğu olan ebeveynlerin, çocuklarının televizyon izleme durumları ve televizyonun çocukları üzerine etkilerine yönelik görüşlerini incelemiştir.

Ebeveynlerin ifadelerine göre; evlerin \%23.0' de 2 televizyon vardır ve çocukların \% 6.2'nin odasında TV bulunmaktadır (Tablo 2) Yapılan bir çalışmada da benzer şekilde çocukların \% 17.4'nin odasında TV bulunmaktadır (Bekar ve Arıkan, 2017). Amerikan Pediatri Akademisi, televizyonun çocuk yatak odalarından çıkarılmasını önermektedir (American Academy of Pediatrics, 2001). Yatak odasında elektronik cihaz bulunmayan çocukların, yatak odasında iki veya üç elektronik cihaz (TV, bilgisayar, video oyunu) olanlardan daha düşük Beden Kitle İndeksine sahip olduğu belirlenmiştir (Ferrari ve ark., 2015). Çocuğun odasında TV bulunması TV izleme süresi ile ilişkili olması nedeni ile çocukların yatak odalarında TV bulundurulmamalıdır.

Çocuklar en çok akşamları TV izlemektedir (Tablo 2). Okul öncesi çocuklarda ev temelli bakıcıllğın sağlandığı durumlarda, kurum bakımına göre uzun süreli TV izlendiği saptanmıştır (Vanderloo, 2014). Ebeveynler, okuldan sonra evde TV izlemenin yerini alabilecek, çocuklara uygun güvenli alternatif faaliyetlerin olmamasına ilişkin endişelerini ifade etmişlerdir (Dorey ve ark., 2010). Yapılan bir çalışmada da en yüksek reyting alan programların bulunduğu 20.00-22.59 saatleri arasında izlenen reklamlarda çocukların olumsuz davranışlara yönlendirilerek ürün tüketicileri haline getirmeyi amaçladığ belirlemiştir (Ezmeci ve ark. 2017). Çalışmaya anaokuluna giden çocuklar alındığı için, akşam evde olan çocuklar daha fazla TV izlemektedir.

Çocukların çoğunluğu 1-2 saat ve üstü TV izlemektedir (Tablo 2). Literatüre göre; 1-6 yaş arasındaki çocukların \%75.6's1 iki saat ve üzerinde TV izlemektedir (Altınkılıç ve Özkan, 2014). Avrupa ülkelerinde yapılan bir çalışmada, 4 - 6 yaş çocukların 20 dakika ila 4 saat TV izledikleri saptanmıştır. En düşük TV izleme süresi 20 - 30 dakika ile Almanya ve İspanya'da bildirilmiştir. Belçika ve İspanya'da sosyo-ekonomik düzeyi düşük ebeveynler çocuklarının daha fazla TV televizyon izlediğini bildirmiştir (De Decker ve ark., 2012 ). Zimmerman ve Christakis' in (2005) çalışmasında 3 yaşından önce, çocukların günde ortalama 2.2 saat; 3 ila 5 yaş arasında, günlük ortalama 3.3 saat TV izledikleri saptanmıştır. Çocukların \% 47.0'i günde 1- 2 saat televizyon

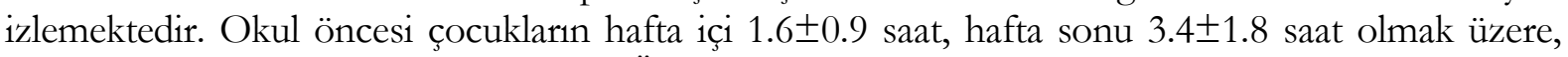
TV izledikleri belirlenmiştir (Akçay ve Özcebe, 2012). Başka bir çalışmada da çocukların \% 67.0'1 günde 120 dakikadan daha fazla bir süre televizyon izlemiştir (Li, Jurkowski ve Davison, 2013). TV izleme süresinin artması şşsmanlık, psikososyal sağlık ve bilişsel gelişimin azalması ile ilişkili bulunmuştur. Televizyon izleme süresi arttkç̧a risklerde artmaktadır . Amerikan Pediatri Akademisi, ebeveynlerin çocuklarının TV izleme süresini 2 saat ile sınırlamasını önermektedir (American Academy of Pediatrics, 2001). Kanada Egzersiz Fizyolojisi Derneği, çocukların hareketsiz kalmamaları için 2 yaşından küçük çocukların TV izlememelerini, 2-4 yaş grubunun da günde 1 saatin altında TV izlemesini önermektedir (Tremblay, 2012). Yurt içi ve dışında yapılan çalışmaların, okul öncesi dönemdeki çocukların evde uzun süreli TV izlediğini göstermesi, çocuk sağlığının değerlendirilmesi için önemli etkenlerden birinin TV izleme süresi olduğunu ortaya koymuştur. 
Demir, K., \& Yıldırım Şişman, N. (2021). Üç - altı yaş arası çocukların ebeveynlerinin görüşlerine göre televizyon izleme ve televizyondan etkilenme durumları. Journal of Human Sciences, 18(3), 349-363. doi:10.14687/jhs.v18i3.6048

Ailelerin \% 49.2'de TV evde 5 - 8 saat açık kalmakta ve TV açıldığında çocukların \% 62.5' nin ara sıra çevreye olan ilgisi azalmaktadır (Tablo 2). Annenin uzun süreli TV izlemesi çocuğunda uzun süreli TV izlemesi ile ilişkili bulunmuştur (Li, Jurkowski ve Davison, 2013). Birçok annebabanın çocuğunun TV karşısında geçirdiği zamanla ilgilenmediği, TV’u çocuk bakıcıllğı ve çocuğun sakinleşmesinde kullandıkları, TV' u dil gelişimi için yararlı ve eğitici olarak gördükleri saptanmıştur (De Decker, 2012). Ebeveynler, çocukları çizgi film seyrederken onunla birlikte izlemediğini, o sırada ev işleri ya da kendi çalışmalarını yaptığını ve bu sürede çocuğun sadece fiziksel ihtiyaçlarını karşıladığını ifade etmişlerdir (Yetim ve Sarıçam, 2016). Uzun süreli TV izlemenin kısıtlanabilmesi için, evlerde TV 'nun uzun süreli açık kalmaması ve ebeveynlerin evde çocukları ile farklı aktiviteler oluşturarak kaliteli zaman geçirmeleri önemlidir.

Çocukların \%43.4'de TV izlemeye bağlı davranış değişimi olmakta, bu değişimin \% $\% 77.5$ 'i de olumsuz davranışlar olmaktadır (Tablo 2). Çocuk programlarının \%61.0’i şiddet içerirken, çizgi filmlerdeki şiddet oranının daha fazla olduğu saptanmıştır (Özen ve Kartelli, 2017). Dört yaşındaki çocukların hiperaktif fakat agresif olmayan davranışlarının, televizyon izlemedeki artışla ilişskili olduğu ortaya konulmuştur (Ansari ve Crosnoe, 2016). TV izleme süresinin azaltılması, çocukların olumsuz davranışlarının da azalmasına yol açabilir.

Çocukların \% 45.7'si 2 yaşından itibaren TV izlemeye başlamıstır (Tablo 2). 3 yaşından önceki televizyon izlemesinin, çocukların bilişsel gelişimi üzerine olumsuz etkileri olduğu bulunmuştur (Zimmerman ve Christakis, 2005). Kanada Egzersiz Fizyolojisi Derneği, çocukların hareketsiz kalmamaları için 2 yaşından küçük çocukların TV izlememelerini, 2-4 yaş grubunun da günde 1 saatin altında TV izlemesini önermektedir (Tremblay ve ark., 2012). Çocuğun sağlıklı gelişimi için, TV izleme yaşının erken yaşlarda olmaması önemlidir.

Çocuklar en çok çizgi film (\%36.4), çocuk programları (\%23.7), belgesel (\%11.5) ve reklamları (\%10.7) izlemektedir. Çocuklar aynı zamanda dizi (\% 5.0), film (\%3.1) ve haber (\%1.8) gibi yetişkine yönelik programları da izlemektedir (Tablo 3). Okul öncesi dönemdeki çocukların sıklıkla çizgi film ve dizi izledikleri, yarışma ve belgesel programlarını ise en az izledikleri belirlenmiştir (Tanyıldızı ve Karabulut, 2018). Çocukların çoğunluğu 2 saat ve üzeri TV' da çocuk programı/çizgi film izlemektedir (Bekar ve Arıkan, 2017). Çocukların çoğunluğunun TV'de sıklıkla çocuk programlarını izlediği ifade edilmiştir (Babaroğlu, 2015). Çocuklar, ebeveynleri ile birlikte TV izlerken yetişkinlere yönelik programları da izlediği için, çocukla birlikte izlenen programların neler olduğu ve içeriği önemlidir (Bilgin, 2011).

Çocuklar TV kahramanlarının en çok (\%39.5) davranış şeklinden etkilenmektedir (Tablo 3). Yapılan bir araştırmada okul öncesi dönem çocukları en çok sevdikleri karakterleri, Selena, Emiray, Keloğlan ve Peri Winx olarak belirtmişlerdir (Tanyıldızı İmik ve Karabulut, 2018). Çizgi film kahramanlarının çocuklarda olumsuz davranışlara neden olduğu, bu olumsuz davranışların ebeveynlere, çocuklarının arkadaşlarına ya da oyuncaklarına yansıdığı, çocukların kendileri içinde fiziksel olarak tehlikeli durumlar yarattıkları ifade edilmiştir (Yetim ve Sarıçam, 2016). Çizgi film kahramanlarının uzun süreli izlemi olumsuz davranışların oluşumu sağlamaktadır.

Çocukların çoğunluğunun (\%64.8) öncelikli etkinlik tercihi oyun olmaktadır (Tablo 3). Ebeveynler, oyunun, hayal gücü, keyif alma ve sosyalleşme gibi sağlık ve gelişimsel olarak faydalı olduğunu bildirirken, TV izlemenin öğrenme, eğitim ve rahatlama gibi faydalar içerirken, alışkanlık oluşumu, uygunsuz içerik, olumsuz bilişsel, sosyal açılardan sağlı̆̆a zararları olduğunu bildirmişlerdir (Hinkley ve McCann, 2018). Çocuklar evde resim yapmaktanda ve bilgisayarda oyun oynamaktan hoşlanmaktadır (Babaroğlu, 2015). Amerikan Pediatri Akademisi (2001), TV dışında alternatif aktivite seçeneklerinin oluşturulmasını önermektedir. Ebeveynlerin çocuklarına kitap okuması çocuğun daha az TV izlemesi ile ilişsili bulunmuştur (Khan ve ark., 2017). Ebeveynlerin, evde bulundukları sürelerde çocukları ile kaliteli vakit geçirmeleri TV 'nun daha az seyredilmesini sağlayacaktır.

Çocukların çoğunluğu (\%71.1) televizyon reklamlarını izlemekte, çoğunlukla (\%73.0) da oyuncak reklamlarını izlemektedirler (Tablo 3). Doğrudan çocuklara mesaj vererek reklamı yapılan 
Demir, K., \& Yıldırım Şişman, N. (2021). Üç - altı yaş arası çocukların ebeveynlerinin görüşlerine göre televizyon izleme ve televizyondan etkilenme durumlar1. Journal of Human Sciences, 18(3), 349-363. doi:10.14687/jhs.v18i3.6048

ürünün alımına yönlendirmeye çalıșan reklamlarda çocuklar olumsuz davranışlara yönlendirilmektedir (Ezmeci ve ark., 2017). Okul öncesi çocuklarda gida reklamcillğ1 da dahil olmak üzere televizyon reklamları şişmanlık ile ilişkili bulunmuştur (Zimmerman ve Bell, 2010). Bu çalışmada literatürden farklı olarak çocukların oyuncak reklamını daha fazla izledikleri bulunmuştur.

Çocukların \%50,0'si TV izleme nedeniyle ara sıra geç yatabilmekte, TV izlemeye bağlı sosyalliğin azalması (\%26.8), kabus görme (\%17.0) ve saldırganlık (\%15.8) sorunu yaşamaktadır (Tablo 3). 1-6 yaş arasındaki çocukların \%75.6'nın 2 saat üzerinde TV izlediği, TV izlerken \%61.2'sinin gözlerde yaşarma, ağrı ve uyku problemleri yaşadığı saptanmıştır (Altınkılıç ve Özkan, 2014). Uzun süre TV izleyen çocukların uyku süreleri kısalmaktadır (Marinelli ve ark., 2014 ). Uzun süreli TV izleme sağlık problemi yaşama ile ilişkilidir.

Ebeveynlerin çoğunluğu TV izlemenin çocuğunun insanlarla olan ilişkisini bazen olumlu bazen olumsuz etkilediğini düşünmektedir (Tablo 4). Uzun süreli TV izleme çocuğun iletişimini ve agresif davranışlarını etkilemektedir (De Decker ve ark., 2012). Uzun süre TV izleyen çocuklarda odaklanamama, şiddet, saldırganlık sorunlarının yaşandığı belirlenmiştir (Yetim ve Sarıçam, 2016). Anne-babaların çoğunluğu (\%84.0) TV izlemenin çocuğunun hayal dünyasını bazen olumlu bazen olumsuz etkilediğini düşünmektedir (Tablo 4). Okul öncesi dönemdeki çocukların TV'da gördükleri kahramanlarla özdeşleşerek, kahramanların özelliklerine sahip olmak istedikleri belirlenmiştir (Tanyıldızı İmik ve Karabulut, 2018 ). Anneler TV'nin çocukların yaratıcılık ve hayal gücünü olumsuz etkilediğini ifade etmişlerdir (Banko, İlhan ve Şallı, 2017).

Ebeveynlerin \% 49.2'si çocuğunun uzun süre TV izlemesinin arkadaşları ile sosyalleşmesi ve oyun oynamasını etkilediğini düşünmektedir (Tablo 4). Ebeveynler, TV'nin çocukların oyunları üzerinde herhangi bir etkisinin olmadığını ifade etmişlerdir (Babaroğlu, 2015). Video, bilgisayar oyunları ve ebeveynlerin çalısması ebeveyn ve çocuğun oyun oynamasını olumsuz etkilediği gibi, zamanının çoğunu medyada harcayan çocukların pasif, ikili ilişkilerde başarısız bireyler olarak yetiştikleri ortaya konmuştur (Özyürek, 2018). Anne-babaların çoğunluğu uzun süre ve kontrolsüz televizyon izlemenin çocukları duyarsızlaştırdığına ve tepkisiz hale getirdiğine inanmaktadır (Tablo 4). Günde 3 saatin üzerinde TV izleyen çocukların, günde 1 saat TV seyreden çocuklara göre daha isyankâr davranışlarda bulunduğu saptanmıştır (Bekar, 2017). Anne-babaların çoğunluğu TV yayınlarının aile içindeki iletişimi bazen olumlu bazen olumsuz etkilediğini düşünmektedir (Tablo 4). Birçok küçük çocuk gördükleri ile gerçek olanlar arasında ayırım yapamadıkları için çocukların TV izleme sürelerinin azaltılması önerilmektedir (American Academy of Pediatrics, 2001). Çocukların çoğunluğu TV programlarını ailesiyle birlikte izlemektedir (Tablo 4). Amerikan Pediatri Akademisi, TV programlarını ailelerin çocukları ile birlikte izlemesini ve içeriği birlikte tartışmalarını önermektedir (American Academy of Pediatrics, 2001). Çocukların \%39.1’i TV istediği zaman açabilmektedir (Tablo 4). Yapılan bir çalışmada çocukların TV izlemelerini denetleyen monitörlerin kullanılması önerilmesine rağmen ebeveynlerin kullanımı konusunda isteksiz olduğu ifade edilmiştedir (Dorey ve ark.,2010).

Anne babalar, çocuklarının TV' u zaman geçirmek (\%25.9), eğitici-öğretici olması (\%22.4), eğlendirici olması (\%22.0) nedeni ile izlediğini ifade etmişlerdir (Tablo 5). Ebeveynler yemek pişirme ve temizlik gibi evdeki işlerini yapabilmek, çocuklarını meşgul etmek çocuklarına TV izlettirerek, TV çocuk bakıcısı gibi kullandıklarını ifade etmişlerdir (De Decker ve ark., 2012; Dorey ve ark.,2010). Ebeveynlerin çocukları ile kaliteli vakit geçirmedikleri için çocukların uzun süreli TV izlediği saptanmıştır (Yetim ve Sarıçam, 2016). Anne babaların \%22.7'si TV izletmeyi bir ödül-ceza aracı olarak kullanmaktadır (Tablo 5). Benzer bir araştırmada da ebeveynlerin TV izlemeyi bir ödül haline getirdiği saptanmıştır (Dorey ve ark., 2010). Anne babaların çoğunluğu çocuklarının televizyonda izlediği kavga, şiddet, terör, gözyaşı içerikli sahnelerden olumsuz etkilendiğini ifade etmektedirler (Tablo 5). Yaşar ve Paksoy'un okul öncesi beş yaş grubu çocuklarla yaptıkları çalışmada saldırgan içerikli çizgi film izleyen çocukların saldırgan unsurları oyunlarında kullanıldığı, eğitici içerikli film izleyen çocukların ise eğitici unsurları kullanmadığı bulunmuştur (Yaşar ve Paksoy, 2011). TV izlerken şiddetten etkilenen çocuklarda sıklıkla ağlama, saldırganlık eğilimi, uyku 
Demir, K., \& Yıldırım Şişman, N. (2021). Üç - altı yaş arası çocukların ebeveynlerinin görüşlerine göre televizyon izleme ve televizyondan etkilenme durumları. Journal of Human Sciences, 18(3), 349-363. doi: $10.14687 /$ ihs.v18i3.6048

bozuklukları, dikkatini odaklaştırma sorunları artmaktadır (Özen ve Kartelli, 2017). Ebeveynlerin çoğunluğu izlenen programlarda şiddet, terör, cinsellik ya da korku sahneleri olduğunda kanalı değiştirmekte ya da TV (\%27.0) kapatmaktadır (Tablo 5). Ebeveynlerin çocukların izlediği çizgi filmler hakkında çocuklarıyla konuşmadıkları saptanmıştır (Yetim ve Sarıçam, 2016). Ebeveynler TV programlarındaki cinsel ve şiddet içerikli programlar konusunda özellikle çocukla durumu konuşamadıklarında endişe duyduklarını ifade etmişlerdir (Dorey, 2010).Bu bağlamda özellikle ebeveynlerin 'TV' nın çocuk gelişimi üzerine etkisi konusunda bilinçlendirilmesi önemlidir.

\section{Sonuç ve öneriler}

$\mathrm{Bu}$ çalışmanın temel bulgusu, 3-6 yaş çocukların günlük olarak evde uzun süre TV izlemeleridir. Evde TV açık kalma sürelerinin uzun olması, çocukların en çok çizgi film ve çocuk programları izlemeleri, çocukların en çok çizgi film kahramanlarının davranışlarından etkilenmeleri, ebeveynlerin çoğunluğunun çocuklarına seçenek sunulduğunda oyun oynayacaklarını düşünmeleri, çocukların çoğunluğunun televizyon izlerken ara sıra geç yattı̆̆, uzun süre televizyon izlemenin çocukların sosyalliklerinin azalmasına, kabus görmelerine ve saldırganlığa sebep olduğu ve televizyonun eğlendirici, eğitici-öğretici olması ve çocuğun zaman geçirmesi için televizyon izletilmesi çalışmanın önemli sonuçlarıdır.

Bu sonuçlar doğrultusunda öneriler:

- Ebeveynler tarafindan çocukların televizyon izleme sürelerinin ve izlenilen program içeriklerinin denetlenmesi,

- 3-6 yaş grubundaki çocukların TV seyretme sürelerinin günde iki saatten fazla olmamas1,

- Çocuğun odasinda TV bulunmamasi,

- Televizyonun evde sürekli aç1k olmamasi,

- Çocuğun izlediği yayınlara ebeveyn ve çocuğun bir arada karar vermesi,

- TV'daki program içeriklerinin çocuklarla konuşulması,

- Çocukların TV dışındaki aktivitelerle zaman geçirmesinin planlanması,

- Çocuklara zararlı içeriği bulunan TV programlarının izletilememesi,

- Aile üyelerinin beraber zaman geçirmeleri ve çocukları ile oyun oynayabilecekleri firsatların oluşturulması,

- TV izleme yerine oyun, kitap okuma, çocuğun yaşına uygun ev işi yapmak gibi alternatif faaliyetlerin oluşturulması,

- Ebeveynlerin çocuklara rol modeli olarak TV izleme sürelerini azaltması,

\section{Çalışma sonuçlarının kullanılabilirliği}

Geleceğe dönük planlamalarda; ebeveynlere, pediatri klinikleri ya da pediatri polikliniklerin de, birinci basamak sağlık kuruluşlarında, okul sağlığı hemşireliği çalışmaları ile çocukların psikososyal gelişimleri açısından medya okuryazarlığı ve TV izlemeye yönelik bilgilendirme eğitimleri yapılarak toplumu bilinçlendirme çalışmaları yapılabilir. Okul öncesi çocukların TV izleme süresini azaltacak randomize kontrollü çalışmalar yapılabilir. Araştırmanın güçlü yönleri; örneklem seçimi, gücün $\% 80$ ve üzerinde olması iken sınırllıklar araştırmanın anketle yapılmasından dolayı anket yönteminin subjektif yönün olması ve hafıza faktörü olarak ifade edilebilir. 
Demir, K., \& Yıldırım Şişman, N. (2021). Üç - altı yaş arası çocukların ebeveynlerinin görüşlerine göre televizyon izleme ve televizyondan etkilenme durumlar1. Journal of Human Sciences, 18(3), 349-363. doi: $10.14687 /$ ihs.v18i3.6048

\section{Kaynakça}

Akçay, D., \& Özcebe, H. (2012). Televizyonun okul öncesi dönemdeki çocukların saldırganlık davranışına etkisi. Çocuk Sağllğı ve Hastalıkları Dergisi, 55(1), 82-7.

Akçay, ZG. (2018). Televizyon Ekranıyla Melezleşen Çocuk Oyunları. Galatasaray Üniversitesi İletişim Dergisi,(29), 115-40. https://doi.org/10.16878/gsuilet.500052.

Altınkılıç, Z., \& Özkan H. (2014).Televizyon izlemenin 1-6 yaş çocuk sağllğı üzerindeki etkilerine yönelik annelerin tutum ve davranışlarının belirlenmesi. İzmir Dr Behçet Uz Çocuk Hast Dergisi, 4(3), 186-94.

American Academy of Pediatrics. (2001). Children, adolescents, and television. Pediatrics,107(2), $423-6$.

Ansari, A., \& Crosnoe, R.(2016). Children's hyperactivity, television viewing, and the potential for child effects. Children and Youth Services Review,61, 135-40. https://doi.org/10.1016/i.childyouth.2015.12.018.

Babaroğlu, ÖGDA. (2015). Televizyonun okulöncesi dönem çocuklarının işbirliği davranışlarına etkisi. JASS,32, 335-55.http://dx.doi.org/10.9761/JASSS2630.

Banko, Ç., İlhan, T., \& Şallı, F. (2017). Okul öncesi dönem çocuklarının ebeveynlerinin akıllı sembol kullanımı ve televizyondan koruma yöntemleri. Erken Çocukluk Çalışmaları Dergisi, 1(1), 45-59. Doi: http://dx.doi.org/10.24130/eccd-jecs.196720171114.

Bekar, P., \& Arıkan, D. (2017). Çocukların televizyon izleme durumlarının davranıs problemlerine etkisi. Turkiye Klinikleri Journal of Nursing Sciences, 9(3), 185-92.

Bilgin Ülken, F. (2011). Televizyon izlemede anne-baba aracılığı ile çocukların saldırgan davranışları arasındaki ilişki. AUSB,11(1), 195-216.

Blanche, MT., Durrheim, K., \& Painter. D. (2016). Research in Practice: applied methods for the social sciens. Second Edition. Cape Town: University of Cape Town Press, 134.

Çelik, A. Otizmli çocukların televizyon izleme davranışlanının yeni medya kullanımlarına etkisi. Yeni Medya, 2019(6), 64-75.

De Craemer, M., De Decker, E., De Bourdeaudhuij, I., Vereecken, C., Deforche, B., Manios, Y., \& Cardon, G.(2012). Correlates of energy balance-related behaviours in preschool children: a systematic review. Obes. Rev, 13(1),13-28.Doi:10.1111/j.1467789X.2011.00941.x.

De Decker E, De., Craemer, M., De Bourdeaudhuij, I., Wijndaele, K., Duvinage, K., Koletzko, B, Grammatikaki, E., Iotova, V., Usheva, N., Fernández-Alvira, J. M., Zych, K., Manios, Y., \& Cardon, G.(2012).Influencing factors of screen time in preschool children: an exploration of parents' perceptions through focus groups in six European countries. Obes. Rev, Obes. Rev, 13(1), 75-84. Doi: 10.1111/j.1467-789X.2011.00961.x.

Dorey, E., Roberts, V., Maddison, R., Meagher-Lundberg, P., Dixon, R., \& Ni Mhurchu, C. (2010).Children and television watching: a qualitative study of New Zealand parents' perceptions and views. Child: Care, Health and Development, 36(3), 414-20. Doi: 10.1111/j.1365-2214.2009.01031.x.

Ezmeci, F., Çoban Söylemez, ET., Akgül, E., \& Akman, B. (2017). Çocukların yer aldığ1 reklamların çocuklara ve yetişkinlere verilen mesajlar, roller ve cinsiyete yönelik ayrımcıllk unsurları açısından incelenmesi. Galatasaray Üniversitesi İletişim Dergisi, (26), 247-79.

Ferrari, GLM., Araújo, TL., Oliveira, LC., Matsudo, V., \& Fisberg, M. (2015). Association between electronic equipment in the bedroom and sedentary lifestyle, physical activity, and body mass index of children. Jornal de pediatria, 91(6), 574-82.

Güngör, M. (2014). Okulöncesi dönem çocuklarının televizyon izleme alışkanlıkları ve anne baba tutumları. Mustafa Kemal Üniversitesi Sosyal Bilimler Enstitüsü Dergisi, 11(28), 199-216. 
Demir, K., \& Yıldırım Şişman, N. (2021). Üç - altı yaş arası çocukların ebeveynlerinin görüşlerine göre televizyon izleme ve televizyondan etkilenme durumlar1. Journal of Human Sciences, 18(3), 349-363. doi: $10.14687 /$ jhs.v18i3.6048

Hinkley, T., \& McCann, JR. (2018). Mothers' and father's perceptions of the risks and benefits of screen time and physical activity during early childhood: a qualitative study. BMC public health. 2018; 18(1): 1271-8. https://doi.org/10.1186/s12889-018-6199-6.

Khan, KS., Purtell, KM., Logan, J., Ansari, A., \& Justice, LM. (2017). Association between television viewing and parent-child reading in the early home environment. Journal of $\begin{array}{llll}\text { Developmental \& } \quad \text { Behavioral Pediatrics,38(7), } & \text { 5oi: }\end{array}$ 10.1097/DBP.0000000000000465.

Kırık, AM. (2013). Televizyonun gelişim çağı çocukları üzerindeki olumsuz etkileri ve ebeveynlerin kontrol sorunu. 21 Yüzyılda Eğitim ve Toplum Eğitim Bilimleri ve Sosyal Araştırmalar Dergisi, 2(3), 189-98.

Koçak, N., Pınarcık, Ö., \& Ergin, B. (2015). Okul öncesi dönem çocuklarının bilişsel gelişim özellikleri ile sosyal becerileri arasındaki ilisskinin incelenmesi (konya örneği). Asian Journal of Instruction, 3(1), 21-9.

Li, K., Jurkowski, JM., \& Davison, KK. (2013). Social support may buffer the effect of intrafamilial stressors on preschool children's television viewing time in low-income families. Childhood Obesity, 9(6), 484. https://doi.org/10.1089/chi.2013.0071.

Marinelli, M., Sunyer, J., Alvarez-Pedrerol, M., Iñiguez, C., Torrent, M., Vioque, J., Turner, M.C., \& Julves J. (2014). Hours of television viewing and sleep duration in children: a multicenter birth cohort study. JAMA Pediatr, 168(5), 458-64. Doi:10.1001/jamapediatrics.2013.3861.

Özen, Ö., \& Kartelli, F. (2017). Türkiye'de yayın yapan çocuk kanallarında yayınlanan çizgi filmlerdeki şiddet olgusunun analizi. Marmara Journal of Communication. 2017; 27(1): 81 93. Doi: $10.17829 /$ midr.20172729523.

Özyürek, A. (2018). Okul öncesi çocukların bilgisayar teknolojileri kullanımının annelerin görüşlerine göre incelenmesi. Çocuk ve Gelişim Dergisi, 2(2), 1-12.

Sussman, S., \& Moran, MB. (2013). Hidden addiction: television. Journal of Behavioral Addictions, 2(3), 125-32. https://doi.org/10.1556/JBA.2.2013.008.

Tanyıldızı İmik, N., \& Karabulut, N. (2018). Okul öncesi eğitime devam eden çocukların televizyon programlarına yönelik tercihlerinin incelenmesi. IJHE, 4(9), 86-102.

Tremblay, MS., LeBlanc, AG., Carson, V., Choquette, L., Connor Gorber, S., Dillman, C., Duggan, M., Gordon, MJ., Hicks, A., Janssen, I., Kho, ME., Latimer-Cheung, AE., LeBlanc, C., Murumets, K., Okely, AD., Reilly, JJ., Stearns, JA., Timmons, BW., \& Spence, JC. (2012). Canadian sedentary behaviour guidelines for the early years (aged $0-4$ years). Appl. Physiol. Nutr. Metab, 37(2), 370-80. Doi:10.1139/H2012-019.

Vanderloo, LM. (2014). Screen-viewing among preschoolers in childcare: a systematic review. BMC Pediatr,14, 205-21. https://doi.org/10.1186/1471-2431-14-205.

Yaşar, M., \& Paksoy, İ. (2011). Çizgi filmlerdeki saldırgan içerikli görüntülerin çocukların serbest oyunlanı sırasındaki saldırganlık düzeylerine etkisi. Ç.Ü. Sosyal Bilimler Enstitüsü Dergisi, 20(2), 279-98.

Yetim, G., \& Sarıçam, H. (2016). Çizgi film programlarının çocuklara etkisi konusunda ailelerin bilgi ve farkındalık düzeylerinin incelenmesi. OPUS Uluslararası Toplum Araştırmaları Dergisi, 6(11), 341-64.

Zhang, G., Wu, L., Zhou, L., Lu, W., \& Mao, C. (2015). Television watching and risk of childhood obesity: a meta-analysis. The European Journal of Public Health, 26(1), 13-8. https://doi.org/10.1093/eurpub/ckv213.

Zimmerman, FJ., \& Bell, JF. (2010). Associations of television content type and obesity in children. Am J Public Health, 100(2), 334-40.doi:10.2105/AJPH.2008.155119.

Zimmerman, FJ., \& Christakis, DA. (2005). Children's television viewing and cognitive outcomes: a longitudinal analysis of national data. Arch Pediatr Adolesc Med,159(7), 619-25. 
Demir, K., \& Yıldırım Şişman, N. (2021). Üç - altı yaş arası çocukların ebeveynlerinin görüşlerine göre televizyon izleme ve televizyondan etkilenme durumlar1. Journal of Human Sciences, 18(3), 349-363. doi:10.14687/jhs.v18i3.6048

\section{Extended English Summary}

Preschool period is a period when social skills develop. The cognitive and social development of children, who are supported in a healthy way, may be more positive in older ages (Koçak, Pınarc1k ve Ergin, 2015). The television (TV) is the most important mass communication tool that affects the child (Güngör, 2014). It is also the most popular entertainment that can be addictive (Sussman ve Moran, 2013). As it is an effective communication tool that appeals to children, the interest of children in development is more intense and they spend their free time in front of TV. This enables them to spend time with their families on TV (K1r1k, 2013). The aim of this study is to examine the opinions of parents who have three to six years old children on the status of their children watching television and the effects of television on their children.

Approval was obtained from the XXX University Health Sciences Institute Ethics Committee Presidency for the research on 2017/02/29 and legal permission was obtained from the XXX National Education Directorate. Written consents were obtained by stating that they are free to participate in the study by giving written information about the study to the parents who have 3-6 years old children, the data obtained will be kept confidential and will not be used anywhere else other than scientific study.

This is a sectional study. The research was carried out between March and May 2017 in 11 kindergartens affiliated to the Ministry of Education, in the Central district of XXX province. The research population consists of 1016 students, aged 3-6, who are enrolled in 11 Kindergartens in the Central district of XXX. Due to the $30.0 \%$ slice among these schools, 306 parents were selected by the stratification method (Blanche ve ark. 2006). 256 parents participated in the study and the participation rate was $80 \%$. A questionnaire form created by reviewing the literature was used as a data collection tool (Kırlk, 2013; De Decker ve ark., 2012; Hinkley ve McCann, 2018; Zhang ve ark., 2015; De Craemer ve ark., 2012; Dorey ve ark., 2010; Yetim ve Sarıçam, 2016; Ferrari ve ark., 2015).

Of the participating parents, $71.9 \%$ were female. Of the families, $23.0 \%$ had two televisions, and $6.2 \%$ of the participating children had a television in their room; $45.7 \%$ started to watch television after the age of two. The television was watched most in the evening hours $(55.1 \%)$ and $63.7 \%$ of the children watched for one or two hours, while $33.6 \%$ watched for three hours or more in a day. The television was kept on for five-eight hours in $49.2 \%$ of the houses. Changes due to watching television were witnessed in the behaviors of $43,4 \%$ of the children, and $77.5 \%$ of these changes were found to be negative. The children watched cartoons (36.4\%), kids' programs $(23.7 \%)$, documentaries $(11.5 \%)$, and advertisements $(10.7 \%)$ the most. Children were found to be most affected by the behaviors of cartoon characters $(39.5 \%)$.

This study indicates that the majority of the children between the ages of three and six years watch television for too long; the child participants watched cartoons and kids' programs, and were influenced by cartoon characters' behaviors the most; a majority of the parents believed that their children would prefer games over television; a majority of the children occasionally slept late after they had watched television; watching television for too long reduced their social activity, and caused them to have nightmares and to be aggressive.

In line with these results;

- $\quad$ Supervision of children's television watching time and program content watched by parents,

- Limiting the watching time of children in the 3-6 age group to more than one or two hours a day,

- $\quad$ No TV in the child's room,

- The television is not always on at home,

- $\quad$ Parent and child decide together on the broadcasts the child watches,

- $\quad$ Exchange of ideas with the child about the program contents while watching TV, 
Demir, K., \& Yıldırım Şişman, N. (2021). Üç - altı yaş arası çocukların ebeveynlerinin görüşlerine göre televizyon izleme ve televizyondan etkilenme durumlar1. Journal of Human Sciences, 18(3), 349-363. doi: $10.14687 /$ jhs.v18i3.6048

- Leading children to meet entertainment ways other than media content, keeping children away from television programs containing harmful elements,

- $\quad$ Spending time with family members and creating opportunities for children to play with,

- $\quad$ Creating alternative activities such as games, reading books and doing chores suitable for the age of the child instead of watching TV.

children.

future-oriented planning; Parents can also make awareness-raising activities in pediatrics clinics or pediatrics outpatient clinics, in primary healthcare institutions, through school health nursing studies and information literacy training for children in terms of psychosocial development and media literacy and watching TV. Randomized controlled studies can be conducted to reduce the time of watching TV for preschool children. The results of watching television in the research are based on the subjective evaluations of the parents. Since the study is cross-sectional, a definite cause-effect relationship cannot be reached from the research results. 